Relations industrielles

Industrial Relations

\title{
Days of Our Years with Labor, par Robert C. Knee, The W.H. Anderson Company, Cincinnati, 1966, 160 pages.
}

\section{Jean Sexton}

Volume 22, numéro 3, 1967

URI : https://id.erudit.org/iderudit/027821ar

DOI : https://doi.org/10.7202/027821ar

Aller au sommaire du numéro

Éditeur(s)

Département des relations industrielles de l'Université Laval

ISSN

0034-379X (imprimé)

1703-8138 (numérique)

Découvrir la revue

Citer ce compte rendu

Sexton, J. (1967). Compte rendu de [Days of Our Years with Labor, par Robert C. Knee, The W.H. Anderson Company, Cincinnati, 1966, 160 pages.] Relations industrielles / Industrial Relations, 22(3), 452-452.

https://doi.org/10.7202/027821ar

Tous droits réservés (C) Département des relations industrielles de l'Université Laval, 1967
Ce document est protégé par la loi sur le droit d'auteur. L'utilisation des services d'Érudit (y compris la reproduction) est assujettie à sa politique d'utilisation que vous pouvez consulter en ligne.

https://apropos.erudit.org/fr/usagers/politique-dutilisation/ 
This book is meant to awaken motivotion obout a variety of labor problems, by its use as a supplement to a textbook in college courses or as the basis for discussion in cdult programs where the participants already have some understanding of labor and industrial relations.

The problems of unemployment, minority welfare, leisure and automation are not more related to union activity than they are to the conduct of others institutionsemployees, schools, civic groups, and political parties, for example. These labor issues need to be presented in their own right-not just in their relation to the organized sector of the labor force. Three chapters, - unemployment, the disadvantaged, work and leisure - provide this kind of presentation. They are in Part one: "The Broad Contexty

Part Two: \&abor's Involvement include six chapters - Is there still a labor Movement? Must Union Membership Decline? Inside the Unions Innovations in Collective Bargaining, the Role of Government in Industriol Relations, Labor and Politics - which are oriented largely, though not completely, oround organized lobor.

Several chapters in each part are divided into sections so that the reader may easily grosp the major issues that are covered.

\section{Pierre DIONNE}

\section{Days of Our Years with Labor,par Robert C. Knee, The W.H. Anderson Company, Cincinnati, 1966, 160 pages.}

Essentiellement, ce livre est une histoire concise du développement du droit du trovoil en Amérique depuis ses débuts. Malgré I'impossibilité de trancher au couteau les trois grandes phases de croissance du droit du trovoil, à sovoir l'ère de la conspiration criminelle, l'ère des injonctions et l'ère interventionniste, l'auteur essaie quand même d'identifier chacune d'elles dans l'histoire des Etats-Unis. Pour refaire, il part de la période pré-révolution civile pour aboutir à la Loi sur les heures de travail de 1962, en passant évidemment par les fameuses lois Wogner, Thaft Hortley, Landum Griffin et Norris Lo Guordio.

Chose remarquable à noter quant à la méthode utilisée, l'auteur se fait un devoir de toujours expliquer le contexte historique qui o entouré l'adoption de chacune des lois influençont le syndicot et l'employeur.

\section{Jean SEXTON}

Labor Relations, by Arthur A. Sloane et Fred Witney, Prentice Hall Iric., Englewood Cliffs, N.J., 1967, 450 poges.

A unified treatment of the labor-manogement field, focusing on collective bargaining, with emphasis on the development and application of today's vital bargaining issues, together with ten orbitration cases to present a practical application of theories, this is Labor Relations.

By means of description, analysis, discussion questions and arbitration cases drawn from the author's own experiences, this book describes all basic phases of labor relations and how they offect the business man.

The direction which this book will take is an obvious one: downward from a brood overview of the general noture of the lobormanagement relationship as it currently exists in the United States (Port 1), through a survey of the historical, legal and structural environments which so greatly influence contractuol contents and labor relation, behovior (Part 2), to a close examination of the negotiation, administration, and major contents of the labor contract itself (Part 3)

Let us reconsider each part separately. In part one, the authors set the stage by explaining the stote of the unions todoy, the reasons for workers to join unions, for manager to resist them, and the management philosophies toword unions.

In part two Sloane and Witney describe the historical framework from the eighteenth century, to the AFL-CIO reality. The outhors also explain in this port both the legol framework, from the era of judiciol control to the Landum Griffin and the union structure, government and operation.

Finally, the main part of this book is dedicated to the collective bargaining; the preparation for negotiations, the bargaining process, the administration of the agreement, the wage issues, the economic supplements, the institutional and administrative issues of collective bargaining.

We could resume the content of this book by describing some of its highlights: 